\title{
FENOMENA PERLUASAN DAN PENYEMPITAN MAKNA DALAM ILMU SEMANTIK
}

\author{
Ahmad Sirfi Fatoni \\ Institut Agama Islam Nurul Hakim, Lombok Barat \\ ahmadsirfi20@gmail.com
}

\begin{abstract}
:
This article examines the expansion and narrowing of meaning in the field of semantics. The reasons that triggers this research because the meaning in one period of time can change and most likely different at other times, this situation occurs because of the development of thinking of language users and cultural changes. From there emerged several phenomena such as the expansion and narrowing of meaning. This research is a qualitative research. As for the research method used descriptive analysis and critical. The findings of the research are: (1) The expansion of meaning is certainly closely related to language use. The language-speaking community in expanding the meaning contained in a word can use analogy or with self-help language itself. Expansion is often caused by social factors. A word that changes its usage from a limited circle into general usage sometimes will expand its meaning and lose some of its distinguishing elements, (2) The expansion of meaning is not only a booster in the development of semantics and method in the development of linguistic science, but on the other side it shows the weakness of a language, especially for common people, (3) The expansion of meaning is the result of the abortion of some the distinguishing features of a word, while the narrowing of meaning is the result of the addition of some the distinguishing features of a word, (4) Narrowing of meaning is found in the realm of scientific and artistic terms, in fact it's closely related to the phenomena of homonym and polysemy.
\end{abstract}

Keywords: Expansion of meaning, narrowing of meaning, semantic science, distinguishing feature

\section{PENDAHULUAN}

Bahasa merupakan masalah yang cukup kompleks dan rumit, bukan saja karena bahasa adalah unsur dan pendukung kebudayaan, melainkan juga karena masalah bahasa mencakup kepentingan segenap lapisan masyarakat yang mencakup strata sosial kelas tinggi, kelas menengah dan kelas rendah. Tidak seorangpun dapat melepaskan keterkaitannya dengan bahasa, baik ditinjau dari aspek waktu, tempat, keadaan maupun fungsional. Bahasa mempunyai fungsi yang sangat kompleks dalam kehidupan manusia baik secara individual maupun secara sosial. Fungsi utama yang dimiliki bahasa adalah sebagai alat komunikasi dan interaksi sosial antar sesama. Tanpa bahasa manusia akan sulit dan kaku dalam berinteraksi antar sesama.
Sebagaimana yang kita ketahui bahwa pemakaian bahasa diwujudkan dalam bentuk leksem dan kalimat. Masyarakat pemakai bahasalah yang menggunakan leksem dan kalimat itu. Sehingga, bahasa akan mengalami perubahan sesuai dengan kebutuhan dan gerak perkembangan masyarakat tertentu. Dengan demikian, dapat kita ketahui bahwa perubahan yang terjadi dalam suatu bahasa bisa menyebabkan berubah maknanya. Fenomena terkait makna merupakan salah satu isu yang sangat penting dalam kajian ilmu linguistik. Ungkapan tentang makna dianggap sebagai masalah yang ambigu. Dalam membahas makna terdapat tiga hal penting yang mana para filosof dan ahli linguistik menghendaki pengungkapannya dengan adanya proses altaudhih atau al-isyrah tentang istilah-istilah terkait makna. Adapun perincian terkait istilah-istilahnya yaitu: 1) Penjabaran makna 
suatu kata secara ilmiah, 2) Pendeskripsian suatu kata secara ilmiah, dan 3) Penjabaran terkait makna untuk suatu hubungan. Sementara itu, Ruth Kempson berpendapat bahwa dalam penjabaran suatu makna ada tiga hal pokok yang perlu diperhatikan yaitu: 1) Kalam atau kata, 2) Kalimat, dan 3) Kebutuhan dari si pembicara untuk suatu hubungan atau korelasi. ${ }^{1}$

Pada hakikatnya, makna dari sebuah kata tidak bersifat statis. Makna secara natural bisa berubah seirama dengan dinamika dan mobilitas perkembangan pemikiran manusia dan derasnya perkembangan laju ilmu pengetahuan dan teknologi. Salah satu faktor yang mengakibatkan adanya pergeseran dan perubahan makna sebuah kata yaitu bahasa itu ditransfer secara turun temurun, bersifat gradual serta tidak berkesinambungan dari satu generasi ke generasi setelahnya. ${ }^{2}$ Dari fakta itu, maka makna bisa mengalami perluasan dan penyempitan. Perluasan dan penyempitan makna juga terjadi akibat dari perubahan wilayah dan letak geografis. ${ }^{3}$

Ahmad Muhammad Qadur dalam bukunya yang berjudul Madkhal Ila Fiqhil Lughoh al-'Arabiyyah ${ }^{4}$ menjelaskan sebagai berikut:

${ }^{1}$ Kamal Musthofa dan Ahmad Hidayatullah Zarkasyi, "Qadhiyyatu Ilmi al-Dalalah 'inda Toshihiko Izutsu”, Jurnal Lisanu ad-Dhad, Vol. 2, No. 1, April 2015, hal. 102.

${ }^{2}$ Qorinta Shinta, "Pergeseran dan Perubahan Makna pada Kolom "Piye Jal" di Harian Suara Merdeka”, Majalah Ilmiah INFORMATIKA, Vol. 1, No. 1, Januari 2010, hal. 68.

3 Stephen Ullmann, Pengantar Semantik, Pent: Sumarsono, (Yogyakarta: Pustaka Pelajar, 2012), hal. 228.

4 Ahmad Muhammad Qadur, Madkhal Ila Fiqhil Lughoh al- 'Arabiyyah, (Damaskus: Daar al-Fikr, 2010), h. 348.

$$
\begin{aligned}
& \text { التطور الدلالي أو تغيُرُ المعنى جزء من التطور } \\
& \text { اللغوي الذي يشمل قطاعاتِ اللغة الرئيسية وهي } \\
& \text { الأصوات والصرف والنحو والمفردات. ومن القوانين }
\end{aligned}
$$

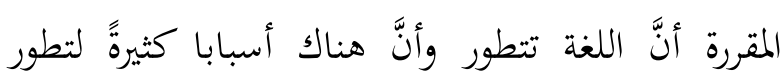

$$
\begin{aligned}
& \text { اللغاتِ. لكن ما يلاحظ في العربية الفصحى خصوصا } \\
& \text { من هذا الموضوع يكاد يكون متميزا ومتفرقًا من غيره مما } \\
& \text { يلاحظ في اللغات الأخرى في العَالَّ. }
\end{aligned}
$$

Atas dasar hal di atas, penelitian ini perlu dilakukan secara mendalam dan detail. Perluasan dan penyempitan makna terkadang memberikan adanya ketaksaan dalam menafsiri atau memberikan makna pada suatu kata. Hal itu dikarenakan satu kata dalam bahasa tertentu bisa bermakna berbeda dalam fase atau periode yang berbeda pula. Itulah problem penting dalam penelitian ini, sehingga nantinya artikel ini bisa menjawab dan memberikan solusi terkait kondisi tersebut. Perlu diketahui, penelitian ini disusun untuk memfokuskan dalam menjelaskan beberapa fenomena perluasan dan penyempitan makna dalam koridor ilmu semantik khususnya dalam bahasa Arab, contoh-contohnya serta faktor-faktor penyebab terjadinya. Penelitian ini akan memberikan kebaruan dalam mengkonstruk teori perluasan dan penyempitan makna secara detail dalam bingkai ilmu semantik.

\section{METODE PENELITIAN}

Penelitian ini termasuk jenis penelitian kualitatif. Metode penelitian yang dipakai yaitu metode deskriptif analisis dan kritis. Objek penelitiannya yaitu tema-tema tentang perluasan dan penyempitan makna dalam bingkai ilmu semantik serta anekavariannya. Data-data dalam penelitian ini dirujuk dari buku-buku ilmu dalalah yang bersifat otoritatif dan orisinil. Adapun terkait teknik pengumpulan data, peneliti menerapkan metode simak dengan teknik catat. Perlu diketahui bersama bahwa metode simak ialah suatu jenis metode di mana pengumpulan data dalam suatu penelitian dilaksanakan dengan 
menyimak penggunaan bahasa, dalam konteks ini bahasa tulisan yang ada dalam buku-buku semantik. Metode simak juga dikenal dengan sebutan metode observasi. Langkahlangkahnya yaitu buku-buku yang mengandung tema perluasan dan penyempitan makna dalam bingkai ilmu semantik diteliti, diamati dan dianalisis secara tepat dan matang oleh peneliti. Hasil pengamatannya yang sudah dilakukan secara bertahap dan kontinu lalu dituangkan dalam sebuah narasi tulisan secara runtut sehingga mudah dipahami oleh pembaca secara tepat. Pada akhir tulisan, peneliti mengintisarikan seluruh hasil penelitiannya dalam sebuah kesimpulan yang sistematis.

\section{PEMBAHASAN}

Secara sinkronis, makna sebuah kata atau leksem tidak akan berubah, tetapi secara diakronis $^{5}$ ada kemungkinan dapat berubah. Maksudnya, dalam masa yang relatif singkat, makna sebuah kata akan tetap sama, tidak berubah, akan tetapi dalam waktu yang relatif lama ada kemungkinan makna sebuah kata akan berubah. Ada kemungkinan ini bukan berlaku untuk semua kosakata yang terdapat dalam sebuah bahasa, melainkan hanya terjadi pada sejumlah kata saja yang disebabkan oleh berbagai faktor dalam beberapa kondisi. Sebagaimana juga yang dikatakan oleh Herakleitos: "Semua mengalir, semua berubah," hal itu juga terjadi pada kata-kata dan makna-maknanya yang mana ikut berubah secara otomatis sesuai dengan perkembangan derasnya zaman. ${ }^{6}$

${ }^{5}$ Hal yang perlu diutarakan bahwa penelitian yang bersifat diakronis diperlukan adanya pemahaman yang mendalam dan detail mengenai sejarah dan asal usul kata dari awal lahir sampai sekarang ini serta perlu adanya pengetahuan tentang kondisi sosial budaya tatkala makna pada sebuah kata berubah. Itulah yang menjadi karakteristik dari penelitian diakronis (Lihat Alan Cruse, A Glossary of Semantics and Pragmatics, (Edinburgh: Edinburgh University Press Ltd, 2006), hal. 2).

6 Henry Guntur Tarigan, Pengajaran Semantik, (Bandung: Angkasa Bandung, 1986), hal. 85.
Perubahan makna dalam koridor ilmu semantik acapkali bersamaan dengan perubahan sosial yang disebabkan oleh perpindahan penduduk, kemajuan teknologi dan ilmu pengetahuan, mobilitas ekonomi, budaya global, peperangan, geopolitik, tradisi lokal, adat istiadat dan lain-lainnya. Perlu diketahui bersama bahwa perubahan makna bisa dikelompokkan menjadi enam macam yaitu: generalisasi, spesialisasi, ameliorasi, peyorasi, sinestesia dan asosiasi. ${ }^{7}$

Ada dua faktor yang menyebabkan terjadinya perubahan makna suatu kata atau ujaran yakni faktor kebahasaan (linguistik) dan faktor sosial. Faktor penyebab terjadinya perubahan makna kata yang bersifat kebahasaan adalah faktor yang ada di dalam atau terkait langsung dengan kata atau ujaran tersebut. Sedangkan faktor sosial adalah faktor yang berkaitan dengan masyarakat penutur, yaitu perkembangan sosial budaya, adat istiadat, tradisi, kondisi psikologis dan lain-lain. Faktor-faktor ini menimbulkan perubahan maknanya, baik meluas atau menyempit. Hal itu bisa kita lihat dalam kasus penyempitan makna umum seperti kata المؤمن، dan juga kasus perluasan makna khusus, seperti kata : الورد، الرائد، النَّجعة، المنيحةُ Hal penting yang perlu ditekankan juga bahwa perluasan makna maupun penyempitan makna sangat erat kaitannya dengan wilayah makna bukan wilayah kata.

Merujuk pada bukunya Ahmad Mukhtar Umar, Ilmu ad-Dalalah, ${ }^{8}$ diuraikan sebagai berikut:

$$
\text { وهي: (1) توسيع المعنى، (2) تضييق المعنى، (3) نقلى إلى أربعة أقسام }
$$

7 Henry Guntur Tarigan, Pengajaran Semantik, (Bandung: Angkasa Bandung, 1986), hal. 85.

8 Ahmad Mukhtar Umar, Ilmu ad-Dalalah, (Kairo: 'Alamul Kutub, 1998), hal. 243. 


$$
\text { المعنى، (4) المبالغة، وفي هذا البحثِ سنشرح عن توسيع }
$$

حاول رجال القواعد العربية وعلماء البلاغة

جاهدين منذ أرسطو أن يخضعوا تغيرات المعنى لشيء

من التنظيم والتعقيد، غير أفم حصروا جهودهم لقرون

طويلة في تصنيف المحازات لأسباب جمالية أو أسلوبية.

وحين انتقل الأمر إلى علماء اللغة حاولوا تنظيم البحث

من عمليات انتقال المعنى دون اعتبار لمضموناها

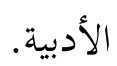

\section{Perluasan Makna (Generalisasi)}

Perluasan makna atau generalisasi adalah proses perubahan makna kata dari yang lebih khusus ke yang lebih umum. ${ }^{9}$ Cakupan makna sekarang lebih luas dari pada makna yang lama atau dapat juga dikatakan perubahan makna dari yang lebih sempit ke yang lebih luas (general). ${ }^{10}$

Perluasan makna tentu berhubungan erat dengan pemakaian bahasa. Masyarakat pemakai bahasa dalam memperluas makna yang terdapat pada sebuah kata dapat menggunakan jalan analogi atau dengan swadaya bahasa itu sendiri. ${ }^{11}$ Perluasan sering juga disebabkan oleh faktor sosial. Sudah kita ketahui bahwa sebuah kata yang berpindah pemakaiannya dari kalangan terbatas ke dalam pemakaian umum kadang-kadang akan

9 Sarwiji Suwandi, Semantik Pengantar Kajian Makna, (Yogyakarta: Penerbit Media Perkasa, 2008), hal 130.

${ }^{10}$ Ibid..., hal 130 .

11 Mansoer Pateda, Semantik Leksikal, (Jakarta: Rineka Cipta, 2010), h. 188. meluas maknanya dan kehilangan beberapa unsur pembedanya. ${ }^{12}$ Contohnya:

- Kata "Mahasiswa" dan kata "Siswa" dalam pemakaian bahasa Indonesia tidak hanya mengacu pada mahasiswa atau pelajar yang berkelamin pria, tetapi juga pelajar yang berkelamin wanita.

- Kata "Bapak/ Ibu" sebenarnya maknanya sebutan untuk orang tua kandung, namun sekarang maknanya digunakan kepada orang yang sudah pantas dipanggil bapak atau ibu, seperti guru, dosen, bos, manager perusahaan, kepala sekolah, rektor kampus, kepala-kepala birokrasi pemerintahan dan yang serupa dengan itu.

- "Berlayar" dulu maknanya adalah mengarungi laut dengan menggunakan kapal layar tanpa mesin. Adapun makna yang sekarang meluas menjadi mengarungi laut dengan alat apa saja, baik memakai layar maupun yang tidak memakai layar, seperti menggunakan tenaga mesin atau motor bahkan ada yang memakai tenaga nuklir. ${ }^{13}$

- "Manuskrip" dulu maknanya yaitu tulisan tangan dan sekarang makanya meluas menjadi naskah baik ditulis tangan maupun diketik di komputer.

- "Saudara" dulu maknanya seibu sebapak saja dan sekarang maknanya meluas menjadi orang yang sama derajat kedudukannya ataupun pangkatnya. ${ }^{14}$

- "Putra/ putri" dulu maknanya anak raja saja yang disebut sebagai putra atau putri, tetapi sekarang maknanya meluas menjadi anak siapa saja baik anak bangsawan, guru,

12 Stephen Ullmann, Pengantar Semantik, Pent: Sumarsono, (Yogyakarta: Pustaka Pelajar, 2012), hal. 284 .

13 Sarwiji Suwandi, Semantik Pengantar Kajian Makna, (Yogyakarta: Penerbit Media Perkasa, 2008), hal 131.

14 Henry Guntur Tarigan, Pengajaran Semantik, (Bandung: Angkasa Bandung, 1986), hal. 87. 
dosen, petani, buruh pabrik, pedagang dan lain-lain. ${ }^{15}$

- "Nasi" dulu maknanya beras yang sudah dimasak, sekarang maknanya meluas menjadi makanan, tidak terbatas pada beras yang sudah dimasak saja.

- "Ikan, dulu maknanya lauk pauk, sekarang maknanya meluas menjadi kawan nasi atau temannya nasi, dalam artian tidak terbatas pada ikan saja. ${ }^{16}$

- “Adik" dulu maknanya yaitu saudara kandung yang lebih muda, sekarang meluas menjadi semua orang yang lebih muda usianya atau lebih rendah kelas dan kedudukannya.

- "Kakak" dulu maknanya saudara kandung yang lebih tua, sekarang maknanya meluas menjadi semua orang yang lebih tua usianya atau lebih tinggi kelas dan kedudukannya.

- "Anak" dulu maknanya keturunan yang kedua, sekarang meluas menjadi semua orang yang lebih muda, perlu pembinaan, bimbingan atau nasehat. ${ }^{17}$

Perlu ditekankan di sini bahwa perluasan makna terbagi menjadi dua: 1) Ta'mimu fushah, ialah perubahan makna suatu kata dari hal yang bersifat khusus menuju ke yang umum dengan syarat dalam perubahan tersebut tidak ditemukan lahn khususnya dalam hal kosakatanya, 2) Ta'mimu amiyah, ialah perubahan makna suatu kata dari hal yang bersifat khusus menuju ke hal yang umum dengan syarat dalam perubahan tersebut ditemukan adanya lahn khususnya dalam hal kosakatanya.

Adapun contoh konkret terkait ta 'mimu fushah sebagai berikut:

15 Mohamad Jazeri, Semantik Teori Memahami Makna Bahasa, (Tulungagung: STAIN Tulungagung Press, 2013), hal. 53.

16 Henry Guntur Tarigan, Pengajaran Semantik, (Bandung: Angkasa Bandung, 1986), hal. 87.

17 Sarwiji Suwandi, Semantik Pengantar Kajian Makna, (Yogyakarta: Penerbit Media Perkasa, 2008), hal 131.
- Kata كلمة dulu maknanya sebelum adanya perubahan ialah اشتقاقٌ من "جرح" في اللغة العِبْرِيَّة، وتُسمَّى الكلمةُ الجحارحةُ الكلمةَ السيئًَ

Sekarang setelah adanya perubahan maknanya meluas secara fushah menjadi الكلمةُ كالعادةِ (kata sebagaimana biasanya) dalam ilmu linguistik.

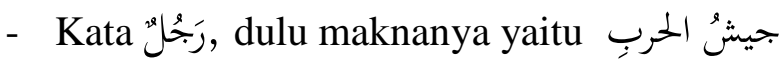
لا يركبُ الحصانَ (prajurit perang yang tidak menunggang kuda), sekarang maknanya meluas menjadi الرجلُ البالغ (laki-laki yang sudah baligh).

- Kata القافلةُ dulu maknanya adalah الحَمَلُ (unta yang mana kembali ke kota kelahirannya atau tanah tumpah darahnya), sekarang maknanya meluas menjadi الجملُ (unta) secara umum.

Sementara itu contoh terkait ta'mimu amiyah sebagai berikut:

- Kata شَ' dulu maknanya sebelum تطَاوُلْ و وَظْرُ (pemanjangan dan pandangan), setelah adanya perubahan secara amiyah maknanya meluas menjadi أيیي (pandangan/ pendapat).

- Kata رَارَ بالعَشِيِ dulu maknanya ialah (berjalan di waktu petang/ senja/ sore), sesudah adanya perubahan secara amiyah maknanya meluas menjadi ذهب (pergi).

- Kata الكَرَجُ الهُ الْمُخْتَكَطُ الَُْ (perkataan yang bercampur), الكامُ (perkataan) secara umum. ${ }^{18}$

18 Arina Istiqomah, Tadyiqul Ma'na fi alMu'jam al-'Ashri li Atabik Ali wa Ahmad uhdi Muhdhar: Dirasah Tahliliyyah Dalaliyyah, Skripsi, 
Ahmad Mukhtar Umar dalam bukunya yang berjudul Ilmu ad-Dalalah menjelaskan tentang perluasan makna sebagai berikut:

$$
\begin{aligned}
& \text { يقع توسيع المعنى أو امتداده عندما يهدث }
\end{aligned}
$$

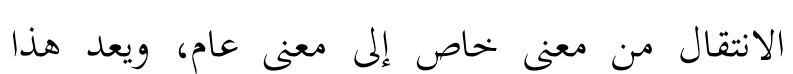

$$
\begin{aligned}
& \text { الشكل على قدم المساوة في الأهمية مع الشكل الآتي } \\
& \text { (تضييق المعنى)، وإن كان الدكتور إبراهيم أنيس يرى أنَّ: } \\
& \text { "تعميم الدلالات أقل شيوعا في اللغات من تخصيصها، } \\
& \text { وأقل أثرا في تطور الدلالات وتغيُّرها." }
\end{aligned}
$$

ويعني توسيع المعنى أن يصبح عددُ ما تشير إليه

الكلمةُ أكثرَ من السابق، أو يصبح بحال استعمالها

أوسع من قبل. والأمثلة على ذلك كثيرة في لغة الصغار

والكبار وفي كل اللغات: (-) كلمة picture كانت

تطلق على اللوحة المرسومة، والآن امتدتْ لتشمَلَ الصور

الفوتوغرَافية، 19 (-) البأسُ، قال ابن سيده: "البأس

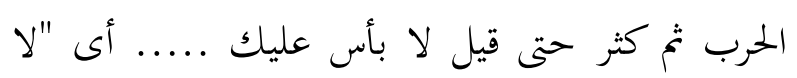

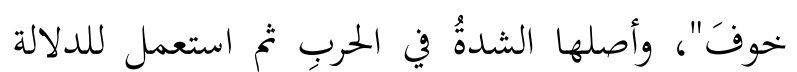

على كل شدةٍ، 20 (-) في اللغات الأَّروبية كلمة

“arrived” التي كانت تعني الوصول إلى شاطئ

$$
\text { النهر ثنَّ بعد ذلكَ أصبحت الآن لمحردٍ الوصول. } 21
$$

Jurusan Bahasa dan Sastra Arab, Fakultas Humaniora, UIN Malang, 2015, hal. 19-20. Lihat juga Taufiqurrahman, Leksikologi Bahasa Arab, (Malang: UIN Malang Press, 2008), hal. 118-119.

19 Ahmad Mukhtar Umar, Ilmu ad-Dalalah, (Kairo: ‘Alamul Kutub, 1998), hal. 243-244.

20 Farid 'Iwad Haidar, Ilmu ad-Dalalah Dirasah Nadzariyyah wa Tathbiqiyyah, (Kairo: Maktabatul adab, 2005), hal. 78.

21 Ibrahim Anis, Dalalah al-Alfadz, (Mesir: Maktabah al-Anjalo al-Mishriyyah, 1958), hal.155156.

$$
\begin{aligned}
& \text { وفى اللغة العربية نلحَظُ ما يشبه تعميم الدلالة } \\
& \text { لدى الأطفال حين يطلقون اسم الشيء على كل ما } \\
& \text { يشبهه لأدنى ملابسة أو مماثلة، وذلك لقصور محصولمم } \\
& \text { اللغوي. وقد يطلق الطفل لفظ "الأب" على كل رجل } \\
& \text { يشبه أباه في هيئته، وقد يطلق لفظ "الأم" على كل } \\
& \text { امرأة تشبه أمَّه في هيئتها. وقد عقد السيوطي مبحثا في } \\
& \text { كتابه "المزهر" عنوانه: "فيما وضع في الأصل خحاصًّا ثم }
\end{aligned}
$$

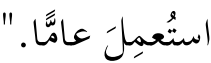

Muhammad Dawud berpendapat bahwa perluasan makna meskipun mencerminkan fenomena dari beberapa fenomena perkembangan semantik, dan jalan untuk memperluas bahasa dari satu sisi, tetapi di sisi lain terkadang juga mencerminkan fenomena dari kelemahan sebuah bahasa, khususnya bagi masyarakat awam. Adapun bukti-bukti konkretnya yaitu kebanyakan orang awam menggunakan kosakata-kosakata secara general tidak ada batasan dan perincian di antara beberepa kosakata tersebut. Mereka cenderung menyamaratakan beberapa istilah yang bersinonim meskipun secara hakikatnya berbeda. Beginilah watak manusia awam dalam kehidupan sehari-harinya, mereka ingin serba praktis tanpa adanya kerepotan dan kerumitan dalam mengucapkan kosakata tertentu. Mereka secara otomatis memindahkan suatu kata yang mempunyai dalalah khusus menuju ke dalalah yang umum, hal itu dalam rangka untuk kemudahan dalam dirinya dan dalam rangka menghindari hal-hal yang bersifat kompleks. Itulah watak orang awam dari dulu hingga sekarang ini. ${ }^{22}$

Perlu ditekankan di sini bahwa kasus perluasan makna masih banyak memicu perdebatan di antara pakar semantik. Sebagian berpendapat bahwa perluasan makna lebih

22 Muhammad Muhammad Dawud, Al'Arabiyyah wa Ilmu al-Lughoh al-Hadist, (Kairo: Daar Ghorib, 2001), hal. 211-212. 
besar terjadi daripada penyempitan makna. Di sisi lain, sebagian besar pakar semantik berpendapat bahwa perluasan makna kurang menarik karena manusia dewasa ini cenderung untuk mempersempit makna dalam dunia spesialisasi dan konkretisasi. Dampaknya banyak kosa kata baru yang muncul belakangan karena adanya kasus penyempitan makna ${ }^{23}$

Proses perluasan makna ini dapat terjadi dalam waktu yang relatif singkat, tetapi juga dapat terjadi dalam kurun waktu yang cukup lama. Namun, yang perlu diingat adalah bahwa makna-makna lain yang terjadi sebagai hasil dari perluasan ini masih berada dalam lingkup poliseminya. Jadi, makna-makna itu masih ada hubungannya dengan makna aslinya, dalam artian tidak lepas begitu saja. ${ }^{24}$

\section{Penyempitan Makna (Spesialisasi)}

Penyempitan makna atau spesialisasi adalah proses perubahan makna dari yang lebih umum menuju yang lebih khusus. ${ }^{25}$ Proses spesialisasi atau pengkhususan mengacu pada suatu perubahan yang mengakibatkan makna kata menjadi lebih khusus atau lebih sempit dalam aplikasinya. Suatu kata pada waktu tertentu dapat diterapkan pada suatu kelompok umum, tetapi belakangan mungkin saja semakin terbatas atau kian sempit dan menjadi lebih khusus dalam kaitannya dengan makna. ${ }^{26}$ Contoh: kata "Da'i" dalam bahasa Arab. Kata ini memiliki makna yang banyak diantaranya, orang yang berdoa, orang yang berda'wah, orang yang memanggil dan lain sebagainya. Namun kata ini maknanya semakin

${ }^{23}$ Parera, Teori Semantik, (Jakarta: Erlangga, 2004), hal. 127.

24 Abdul Chaer, Pengantar Semantik Bahasa Indonesia, (Jakarta: Rineka Cipta, 1990), hal. 141.

25 Sarwiji Suwandi, Semantik Pengantar Kajian Makna, (Penerbit Media Perkasa, 2008), hal 132.

26 Henry Guntur Tarigan, Pengajaran Semantik, (Bandung: Angkasa Bandung, 1986), hal. 88. menyempit yaitu penda'wah saja. Contoh lain adalah:

- Kata "Motor" makna aslinya semua alat penggerak. Kemudian mengalami penyempitan makna sebagai sepeda motor.

- Kata "Kitab" dalam bahasa Arab semula bermakna semua jenis buku, namun sekarang digunakan untuk menunjuk pada buku-buku suci atau keagamaan.

- Kata "Sarjana" mulanya berarti orang pandai atau cendekiawan, kemudian maknanya menyempit menjadi orang yang lulus dari Perguruan Tinggi saja.

- Kata "Pendeta" mulanya dipakai untuk orang yang pandai atau orang yang berilmu, kemudian maknanya menyempit menjadi ulama kristen atau pemimpin agama kristen. ${ }^{27}$ Dalam bahasa Malaysia masih ada sisanya, yaitu Za'ba, seorang tokoh penulis tata bahasa Melayu sering disebut sebagai pendeta bahasa. Akan tetapi dalam bahasa Indonesia kata "pendeta" sudah menyempit maknanya karena hanya berarti "guru agama kristen." 28

- Kata "Bau" dulu maknanya ialah aroma wangi maupun busuk, tetapi sekarang bemakna aroma busuk saja.

- Kata "Ahli" dulu makna lamanya ialah anggota dalam satu keluarga, akan tetapi maknanya sekarang menyempit menjadi orang yang pandai saja.

- Kata "Romo" dulu makna lamanya adalah orang tua atau bapak, tetapi sekarang maknanya yaitu pemimpin agama katholik saja.

- Kata "Ustadz" dulu makna lamanya ialah guru, tetapi sekarang maknanya menyempit menjadi guru agama islam saja. $^{29}$

27 Henry Guntur Tarigan, Pengajaran Semantik, (Bandung: Angkasa Bandung, 1986), hal. 88.

28 Abdul Chaer, Pengantar Semantik Bahasa Indonesia, (Jakarta: Rineka Cipta, 1990), hal. 142.

29 Mohamad Jazeri, Semantik Teori Memahami Makna Bahasa, (Tulungagung: STAIN Tulungagung Press, 2013), hal. 54. 
- Kata "Sastra" dulu maknanya adalah tulisan, sekarang maknanya menyempit menjadi karya seni bahasa atau tulisan yang bersifat seni. Ada juga yang mengatakan bahwa makna sastra sekarang ialah cerita yang baik isinya dan bersifat imajinatif kreatif.

- Kata "Abad" dulu bermakna masa seratus tahun, sekarang maknanya menyempit menjadi seratus tahun saja.

- Kata "Kembang" dulu maknanya mekar atau mengurai, sekarang maknanya menyempit menjadi bunga saja.

- Kata "Gadis" dulu maknanya anak dara atau anak perempuan yang sudah patut kawin, sekarang maknanya menyempit menjadi perawan saja.

- Kata "Pembantu" dulu bermakna semua orang yang memberi bantuan, sekarang maknanya menyempit menjadi babu atau pembantu rumah tangga.

- Kata "Preman" dulu mempunyai makna partikelir atau bukan tentara, sekarang maknanya menyempit menjadi brandalan. ${ }^{30}$

- Kata "Nasib" dulu maknanya untung maupun malang, sementara sekarang maknanya menyempit menjadi keadaan yang malang atau buruk saja.

- Kata "Madrasah" dulu maknanya adalah sekolah, sekarang maknanya menyempit menjadi sekolah agama islam.

- Kata "ke belakang" dulu maknanya pergi ke tempat yang memang berada di belakang, sekarang berubah maknanya menyempit menjadi buang air besar atau air kecil. ${ }^{31}$

Perlu diketahui bahwa penyempitan makna dapat dibagi menjadi dua bagian: 1)

30 Henry Guntur Tarigan, Pengajaran Semantik, (Bandung: Angkasa Bandung, 1986), hal. 88-89. Lihat juga Sarwiji Suwandi, Semantik Pengantar Kajian Makna, (Yogyakarta: Penerbit Media Perkasa, 2008), hal 122.

31 Sarwiji Suwandi, Semantik Pengantar Kajian Makna, (Yogyakarta: Penerbit Media Perkasa, 2008), hal 132.
Takhshishu fushah, ialah perubahan makna yang terjadi dari hal umum ke hal yang khusus dengan syarat perubahan tersebut khususnya terkait kosakatanya tidak mengandung lahn. Hal tersebut bisa ditemukan pada kosakata-kosakata lampau sebelum adanya tadwin al-lugah, 2) Takhshishu amiyah, ialah perubahan makna dari suatu kata yang terjadi dari hal yang umum ke hal yang khusus dengan syarat perubahan yang terjadi khususnya terkait kosakata mengandung adanya lahn. Situasi itu dapat terjadi dengan tidak adanya pemilihan istilah yang tepat sehingga mengakibatkan munculnya sebuah lahn.

Adapun contoh dari Takhshishu fushah sebagai berikut:

- Kata الطبُ dulu maknanya ialah العمل الحاذقُ (pekerjaan yang tajam atau berat), kemudian setelah adanya perubahan, maknanya menyempit menjadi العِلاججُ السِّحرُ (pengobatan/ sihir).

- Kata مَأْتَعْ اجتماع dulu maknanya yaitu (perkumpulan), lalu sesudah adanya perubahan, maknanya menyempit menjadi اجتماعُ للْعَزاءِ (perkumpulan dalam rangka hiburan atau kenyamanan).

- Kata السََُّّْْْ (masa/ waktu), setelah adanya perubahan secara fushah maknanya menyempit menjadi يومُ السببت (hari sabtu). ${ }^{32}$

Sementara itu, contoh dari Takhshishu amiyah sebagai berikut:

32 Arina Istiqomah, Tadyiqul Ma'na fi alMu'jam al-'Ashri li Atabik Ali wa Ahmad uhdi Muhdhar: Dirasah Tahliliyyah Dalaliyyah, Skripsi, Jurusan Bahasa dan Sastra Arab, Fakultas Humaniora, UIN Malang, 2015, hal. 17-18. Lihat juga Taufiqurrahman, Leksikologi Bahasa Arab, (Malang: UIN Malang Press, 2008), hal. 115. 
- Kata الطظارةُ dulu maknanya ialah النظهُ (kebersihan), setelah adanya perubahan secara amiyah maknanya menyempit menjadi الحنتانُ (khitanan).

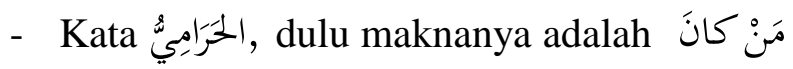
من عادتهِ ارتكابُ ب الحرام kebiasaannya melakukan hal yang haram), sesudah adanya perubahan secara amiyah maknanya menyempit menjadi السارقُ (pencuri).

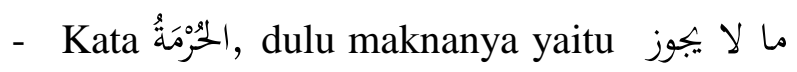
انتهاكُهُ من مالٍ أو نفسِ أو عَرْضِ (sesuatu yang tidak boleh dilanggar yaitu berupa harta, badan/ jiwa dan kehormatan), setelah adanya perubahan secara amiyah الزوجة أو المرأة (istri/ perempuan). ${ }^{33}$

Ahmad Mukhtar Umar dalam bukunya yang berjudul Ilmu ad-Dalalah menjelaskan penyempitan makna sebagai berikut:

ويُعَدُّ تضييق المعنى (narrowing) - وسماه إبراهيم

أنيس تخصيص المعنى أو تقليص المعنى (restriction) ابتحاها عكس السابق، ويعني ذلك تحويل الدلالة من المعنى الكلي إلى المعنى الجزئيِّ أو تضييقُ بحالها، وعرَّفه بعضهم بأنه تحديد معاني الكلمات وتقليلُها. والأمثلة على ذلك كثيرةٌ منها: (-) في أمريكا منذ عشر سنوات

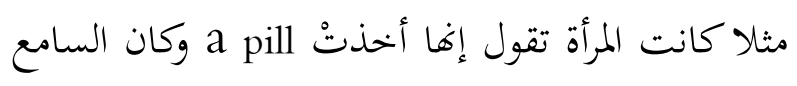
الفضولي يتساءل: لأيِّ غرضٍٍ لمنع الحملِ؟ لعلاجِ

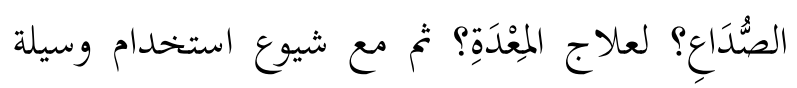
birth control pill منع الحمل عن طريق الأقراص

33 Ibid., Tadyiqul Ma'na fi al-Mu'jam al'Ashri..... hal. 18. Lihat juga Ibid., Leksikologi Bahasa Arab, hal. 115.
صارت كلمة pill ضيقةَ المعنى وأصبحت تعني فقط "قرصُ منعِ الحَمْلِ". (-) كلمة Mete في الإنحليزية

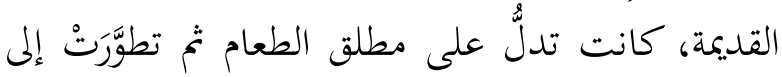
meate ويمكن تفسير التخصيص أو التضييق بعكس ما

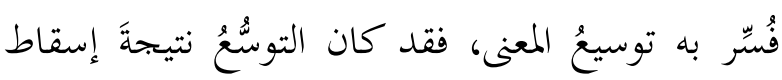

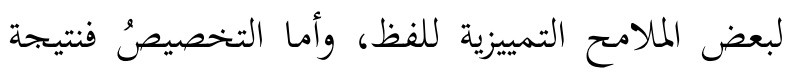

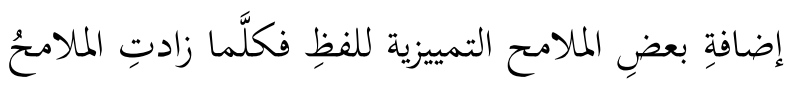
لشيء ما قل عدد أفرادِه. 35

ويرى الدكتور إبراهيم أنيس أنَّ السبب في التغير

نحو التخصيص يرجع إلى أن الناس في حياهم ينفرِورن

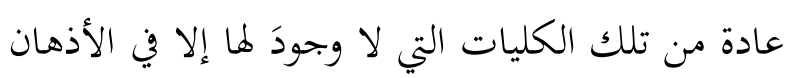
ويؤثرون الدلالات الخاصة التي تعيش معهم فَيَرَوها ويسمعوفا ويَلمسوفا ولذا يسهل عليهم تداولها والتعامل بها في حياة أكثر ما فيها ملموس محسوس .... فإذا قدر لمثل هذا الاستعمال في الدلالة أن يشيع ويذيع بين جمهور الناس رأينا اللفظ تتطور دلالثُه من العموم إلى ميلى الخصوص، ويضيق مجالها وتقتصر على ناحية منها، وذلك هو العرض الذي نسميه بتخصيص الدلالة. 36

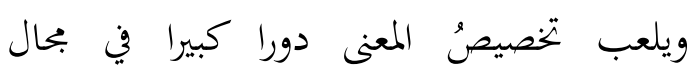
المصطلحات العلمية والفنية، فكثير من العلوم تستدعي

34 Farid 'Iwad Haidar, Ilmu ad-Dalalah Dirasah Nadzariyyah wa Tathbiqiyyah, (Kairo: Maktabatul Adab, 2005), hal. 76.

35 Ahmad Mukhtar Umar, Ilmu ad-Dalalah, (Kairo: 'Alamul Kutub, 1998), hal. 245-246 .

${ }^{36}$ Musthafa Muhammad Abdul Majid Khudur, Al-Alfadz wa ad-Dalalah fi Bashairi Dzawi at-Tamyiz. fi Lathaifil Kitab al-'Aziz li Fairuz Abadi, Muqaddimah: Thahir Sulaiman Hamudah, (Iskandaria: Muassasah Huras ad-Dauliyyah, 2010), hal. 198. 


$$
\begin{aligned}
& \text { الكلماتِ وبتردها من معناها اللغوي وتقصرها على } \\
& \text { معناها الاصطلاحي، حتى إن الكلمة الواحدة يصبح لها } \\
& \text { أكثر من معنى اصطلاحي، مثل: المضارع، يقصد به في } \\
& \text { علم النحو، الفعل الدال على حدوث شيء في زمن } \\
& \text { التكلم أو بعده، ويراد به في العروض6 بحرّ من بكور } \\
& \text { الشعر. وقد عقد السيوطي مبحثا في كتابه "المزهرو" } \\
& \text { عنوانه: "فيما وُضع عاما واستُعمل خاصًَا. "37" }
\end{aligned}
$$

Perlu diketahui di sini bahwa penyempitan makna yang terjadi pada suatu kata dapat berhubungan langsung dan juga dapat tidak berhubungan sama sekali dengan makna yang dirumuskan sebelumnya. Proses liku-liku yang cukup lama dan panjang serta adanya kesepakatan bersama dari suatu masyarakat merupakan tantangan dan rintangan berat yang perlu dihadapi dan diatasi supaya peyempitan makna dapat diterima secara bersama tanpa adanya kejanggalan dan kesalahpemahaman. ${ }^{38}$ Sehingga rentang waktu yang cukup panjang meskipun makna suatu kata itu berubah misalnya maknanya menjadi sempit tidak akan memicu gejolak yang pelik dalam hal penggunaannya di dunia nyata.

\section{KESIMPULAN}

Berdasarkan penelitian di atas, maka dapat disimpulkan beberapa hal pokok diantaranya: (1) Sejalan dengan sifat masyarakat yang dinamis, bahasa yang dipergunakan masyarakat pemakaiannya untuk berkomunikasi juga senantiasa berkembang. Bahasa berkembang selaras dengan perkembangan pemikiran manusia, perkembangan kebudayaan dan peradaban

37 Muhammad Muhammad Dawud, Al'Arabiyyah wa Ilmu al-Lughoh al-Hadist, (Kairo: Daar Ghorib, 2001), hal. 212-213.

38 Erlan Aditya Ardiansyah, "Penyempitan Makna Amelioratif pada Nomina dalam Bahasa Inggris”, Diglosia, Vol. 3, No. 3, 2020, hal. 331. masyarakat pemakainya. Hal ini merupakan sebagian dari penyebab terjadinya makna suatu kata berubah, baik menjadi meluas atau malah semakin menyempit. Kata yang dahulu bermakna X sekarang dapat bermakna Y, dan mungkin kelak dapat berubah lagi bermakna $\mathrm{Z}$ atau bermakna lain. Oleh karena itu, dari peristiwa tersebut dapat menimbulkan perluasan dan penyempitan makna suatu kata kepada makna yang lain. Akan tetapi antara beberapa makna yang timbul dari satu kata tadi masih ada keterkaitan dan relasi yang signifikan, hal itu bisa dianalisis dengan teori medan makna dalam ilmu semantik; (2) Perluasan makna sering terjadi di kalangan orang-orang awam, karena mereka cenderung mengambil sikap untuk menggeneralisir, tidak suka dengan hal-hal yang spesifik dan rumit. Bahkan perluasan makna ini sering terjadi di kalangan anak-anak balita, sekitar umur satu sampai 5 tahunan. Adapun penyempitan makna sering terjadi di kalangan orang-orang yang berkutat dan berkecimpung di dunia tertentu, misal orang yang ahli dalam dunia kedokteran, dunia pelayaran, dunia teknik industri, dunia teknik mesin dan lain-lain. mereka cenderung berpikir untuk menyempitkan makna, karena mereka termasuk orang-orang peneliti yang mana dituntut untuk mencari fitur-fitur pembeda antara satu kata dengan yang lain, sehingga terciptalah temuan-temuan baru; (3) Perluasan makna terjadi jika fiturfitur pembeda semakin sedikit, hal itu akan memicu keterlambatan munculnya kosakata baru. Sementara itu penyempitan makna terjadi dengan cepat jika fitur-fitur pembeda tersebut ditemukan dan jumlahnya sangat banyak. Situasi itulah yang menyebabkan timbulnya banyak kosakata baru dalam suatu bahasa ataupun dalam bidang tertentu. Oleh karena itu, bisa kita katakan bahwa antara perluasan dan penyempitan makna akan selalu terjadi tarik menarik antara keduanya, mana yang kuat itulah yang nantinya menang. Dalam era modern sekarang banyak terjadi penyempitan makna, karena perkembangan ilmu pengetahuan dan teknologi yang amat pesat. Hal itu bisa kita lihat dalam dunia elektronik, seperti hp, laptop, netbook, 
gadget, kamera, tv, tablet, komputer dan lainlainnya. Di situ kalau diteliti secara mendalam, kita akan mendapatkan banyak sekali fitur-fitur pembedanya. Dampaknya bahasa akan selalu berkembang mengikuti perjalanan zaman.

\section{DAFTAR PUSTAKA}

Abdul Chaer, Pengantar Semantik Bahasa Indonesia, (Jakarta: Rineka Cipta, 1990).

Ahmad Muhammad Qadur, Madkhal Ila Fiqhil Lughoh al-'Arabiyyah, (Damaskus: Daar al-Fikr, 2010).

Ahmad Mukhtar Umar, Ilmu ad-Dalalah, (Kairo: 'Alamul Kutub, 1998).

Alan Cruse, A Glossary of Semantics and Pragmatics, (Edinburgh: Edinburgh University Press Ltd, 2006).

Arina Istiqomah, Tadyiqul Ma'na fi alMu'jam al-'Ashri li Atabik Ali wa Ahmad Zuhdi Muhdhar: Dirasah Tahliliyyah Dalaliyyah, Skripsi, Jurusan Bahasa dan Sastra Arab, Fakultas Humaniora, UIN Malang, 2015.

Erlan Aditya Ardiansyah, "Penyempitan Makna Amelioratif pada Nomina dalam Bahasa Inggris", Diglosia, Vol. 3, No. 3, 2020.

Farid 'Iwad Haidar, Ilmu ad-Dalalah Dirasah Nadzariyyah wa Tathbiqiyyah, (Kairo: Maktabatul Adab, 2005).

Henry Guntur Tarigan, Pengajaran Semantik, (Bandung: Angkasa Bandung, 1986).

Ibrahim Anis, Dalalah al-Alfadz, (Mesir: Maktabah al-Anjalo al-Mishriyyah, 1958).

Kamal Musthofa dan Ahmad Hidayatullah Zarkasyi, "Qadhiyyatu Ilmi al-Dalalah inda Toshihiko Izutsu”, Jurnal Lisanu ad-Dhad, Vol. 2, No. 1, April 2015.

Mansoer Pateda, Semantik Leksikal, (Jakarta: Rineka Cipta, 2010).
Mohamad Jazeri, Semantik Teori Memahami Makna Bahasa, (Tulungagung: STAIN Tulungagung Press, 2013).

Muhammad Muhammad Dawud, Al'Arabiyyah wa Ilmu al-Lughoh alHadist, (Kairo: Daar Ghorib, 2001).

Musthafa Muhammad Abdul Majid Khudur, Al-Alfadz wa ad-Dalalah fi Bashairi Dzawi at-Tamyiz fi Lathaifil Kitab al'Aziz li Fairuz Abadi, Muqaddimah: Thahir Sulaiman Hamudah, (Iskandaria: Muassasah Huras ad-Dauliyyah, 2010).

Parera, Teori Semantik, (Jakarta: Erlangga, 2004).

Qorinta Shinta, "Pergeseran dan Perubahan Makna pada Kolom "Piye Jal" di Harian Suara Merdeka", Majalah Ilmiah Informatika, Vol. 1, No. 1, Januari 2010.

Sarwiji Suwandi, Semantik Pengantar Kajian Makna, (Yogyakarta: Media Perkasa, 2008).

Stephen Ullmann, Pengantar Semantik, Pent: Sumarsono, (Yogyakarta: Pustaka Pelajar, 2012).

Taufiqurrahman, Leksikologi Bahasa Arab, (Malang: UIN Malang Press, 2008). 